\title{
A National Geoscience Data Platform and its Application in Paleobiodiversity Studies: Experiences from Estonia
}

\author{
Olle Hints ${ }^{\ddagger}$, Mare Isakar ${ }^{\S}$, Ursula Toom ${ }^{\ddagger}$ \\ ‡ Tallinn University of Technology, Department of Geology, Tallinn, Estonia \\ $\S$ University of Tartu, Natural History Museum, Tartu, Estonia
}

Corresponding author: Olle Hints (olle.hints@taltech.ee)

Received: 05 Jul 2019 | Published: 10 Jul 2019

Citation: Hints O, Isakar M, Toom U (2019) A National Geoscience Data Platform and its Application in

Paleobiodiversity Studies: Experiences from Estonia. Biodiversity Information Science and Standards 3: e38001. https://doi.org/10.3897/biss.3.38001

\begin{abstract}
Studying deep time biodiversity and environments is largely based on collections of fossils and sedimentary rocks, and the information acquired thereof. The sedimentary bedrocks of Estonia and neighbouring areas constitute a well-preserved archive of Earth history from the late Precambrian to the Devonian period. This interval of geological time hosts several key events in the diversification of life, notably the Cambrian explosion, the Great Ordovician Biodiversification Event and the Hirnantian mass extinction. Documenting and understanding these events has benefited from the geological and paleontological collections from the Baltic region, a large part of which are deposited in Estonia.

Since 2004 Estonia has had a 'national geological collection' that virtually joins the archives of three major collection-holding institutions: Tallinn University of Technology, University of Tartu and the Estonian Museum of Natural History (Hints et al. 2008). A key to the functioning of this national consortium is the common database system 'SARV', which started as a simple collection management tool, but has grown into a geoscience data platform linking various types of geoscientific information and supporting also the needs of researchers. Technically the system is based on a relational data model and central database server, a REST API and a number of web-based user interfaces from data
\end{abstract}


management tools to public portals and more specialized applications. Individual components of the system are now built on open source software including MySQL, Apache Solr, Django REST framework, and Angular and Vue JavaScript frameworks. The data model and all recently developed software are available in a Github repository (https:// github.com/geocollections).

Data on individual fossil specimens, digital images, localities, regional stratigraphic units, rock samples, datasets, published references, field notebooks etc. are publicly accessible in the Estonian geoscience collections portal (https://geocollections.info). A separate gateway provides access to the information on fossil taxa and their distribution in the Baltic region (https://fossiilid.info). Another example of using the same underlying data platform specifically for paleobiodiversity research is the Baltic chitinozoan database CHITDB (http://chitinozoa.net; Hints et al. 2018). Chitinozoans are an enigmatic group of Paleozoic microfossils, very useful in biostratigraphy. Some of the largest collections of these fossils worldwide derive from the Baltica paleocontinent and are deposited in Estonia. The chitinozoan portal was developed for managing and publishing the occurrence-level data on chitinozoans, and for quantitatively analysing their diversification history and biotic crises through the Ordovician and Silurian periods. The main benefit of using such an integrated data system is that a user may easily turn back to individual samples and specimen images (for instance, to verify identifications), and combine the paleontological data with information about past environments and climate that might derive from publications, first-hand geochemical data or even from descriptions in field notebooks. Global tools, such as the Paleobiology database, cannot provide such functionality for the time being.

The next steps in enhancing the national geoscience data platform in Estonia are related to the development of new data collection and publication modules, building a complete digital library of geoscience publications related to Estonia and widening the user base of the system. Participation in the national research infrastructure roadmap project NATARC as well as the Pan-European DiSSCo will support achieving this and safeguarding the sustainability of geoscience data and corresponding e-services in Estonia.

\section{Keywords}

geoscience collections, fossils, paleobiodiversity, database, repository, e-service

\section{Presenting author}

Olle Hints 


\section{Presented at}

Biodiversity_Next 2019

\section{Funding program}

National Research Infrastructure Roadmap of Estonia: Natural History Archives and Information Network (NATARC)

\section{References}

- Hints O, Isakar M, Hints R (2008) Geological collections in Estonia. In: Parmasto E, Viikberg J (Eds) Eesti humanitaar- ja loodusteaduslikud kogud. Seisund, kasutamine, andmebaasid. Tartu University Press, Tartu, 181-200 pp. [In Estonian with English summary].

- Hints O, Antonovitš L, Bauert G, Nestor V, Nõlvak J, Tammekänd M (2018) CHITDB: a database for documenting and analysing diversification of Ordovician-Silurian chitinozoans in the Baltic region. Lethaia 51 (2): 218-227. https://doi.org/10.1111/let.12249 